\title{
ROMAN CITIZENSHIP AND THE INTEGRATION OF WOMEN INTO THE LOCAL TOWNS OF THE LATIN WEST
}

\author{
Emily A. Hemelrijk
}

To what extent were women in provincial cities of the Latin West integrated into Roman society? Was there a gender barrier to integration and how can we measure integration? These questions are the starting point of my enquiry. In this paper, I shall try to shed some light on women's integration (or lack of integration) into civic life by looking at Romanization and the spread of Roman citizenship. ${ }^{1}$ Let me start with an example of the difficulties that confront us in trying to assess the integration of women. It has often been observed that on many tombstones in the northern and north-western provinces women are portrayed in indigenous dress, while their husbands wear Roman clothing. ${ }^{2}$ This is usually explained as a sign that women were less integrated into Roman society. Their domesticity and exclusion from politics meant - so it is supposed that they were less influenced by Roman culture than men. In support of this view, some scholars point to epitaphs, which in some provinces show

1 Despite pertinent criticisms of this much-debated concept, aptly summarized by D.J. Mattingly, Imperialism, Power, and Identity. Experiencing the Roman Empire (Princeton and Oxford 2011), 38-40 and 204-207, I shall here retain "Romanization" for want of a better term to cover the multifarious processes of interaction within the Roman Empire, leading both to assimilation and integration, and to divergence and local cultures. For a more detailed discussion of these processes, see the article by Frederick Naerebout in the present volume.

2 Examples are found especially in the German provinces, but also in Raetia, Noricum and Pannonia, see J. Garbsch, Die norisch-pannonische Frauentracht im 1. und 2. Jahrhundert (Munich 1965). For discussion see P. Zanker, 'Bürgerliche Selbstdarstellung am Grab im römischen Kaiserreich', in H.-J. Schalles, H. von Hesberg and P. Zanker (eds), Die römische Stadt im 2. Jahrhundert n. Chr. Der Funktionswandel des öffentlichen Raumes. Kolloquium in Xanten vom 2. bis 4. Mai 1990 (Cologne 1992), 346-347; U. Rothe, Dress and Cultural Identity in the Rhine-Moselle Region of the Roman Empire (Oxford 2009, BAR 2038), 65-66, 69-72; M.L. Okun, The early Roman frontier in the Upper Rhine area: assimilation and acculturation on a Roman frontier (Oxford 1989, BAR 547), 112-113 and 135-136, G. Kremer, 'Die norischpannonischen Grabbauten als Ausdruck kultureller Identität?', in A. Schmidt-Colinet (ed.), Lokale Identitäten in Randgebieten des Römischen Reiches: Akten des Internationalen Symposiums in Wiener Neustadt, 24.-26. April 2003 (Vienna 2004), 152 and 154-155. 
more indigenous names for women than for men, ${ }^{3}$ or to a famous saying in Cicero's De Oratore about women's old-fashioned diction, which Cicero attributed to their retired way of life. ${ }^{4}$ Thus, the notion that women were less integrated in Roman society is widespread. But should local dress and indigenous names on tombstones indeed be regarded as proof of women's lack of integration? Moreover, is it legitimate to generalize from these examples to all women?

Before I continue, I should briefly define what I understand by 'integration'. In line with the description in the call for papers for this conference, I see it as a "process of inclusion". My questions, therefore, are: to what extent were women in the Latin-speaking provinces "included" in Roman society or, in other words, how much were they affected by Roman culture and involved in Roman civic life? Secondly, what stimulated, or impeded, their 'integration'? I shall focus on two aspects that may serve as criteria: first, I shall briefly discuss women's adoption of Roman culture, particularly of Roman dress, customs and values. After that, I shall turn to their participation in civic life, paying special attention to activities that were

3 See S. Fontana, 'Leptis Magna. The Romanization of a major African city through burial evidence', in S. Keay and N. Terrenato (eds), Italy and the West. Comparative Issues in Romanization (Oxford 2001), 167-170 on names in epitaphs from Lepcis Magna in northern Africa, who concludes: "the process of Romanization also seems to affect only minimally women, relegated to a domestic life removed from power" (p. 170) and L.A. Curchin, 'Social relations in central Spain: patrons, freedmen and slaves in the life of a Roman provincial hinterland', Ancient Society 18 (1987), 85: "a strong tradition of indigenous names persisted among females (who were, after all, less likely to require a romanized image for career purposes)." On names and Romanization in general, see B. and H. Galsterer, 'Romanisation und einheimische Traditionen', in Schalles, von Hesberg and Zanker 1992, op. cit. (n. 2), 377-379.

4 D. Cherry, Frontier and Society in Roman North Africa (Oxford 1998), 156-157. Cic. De Or. 3.45 (the speaker is the orator L. Licinius Crassus): "For my own part when I hear my wife's mother Laelia - since it is easier for women to keep the ancient way of speaking unspoiled, as they do not converse with great numbers of people and so always retain the vocabulary and accents they heard first - well, I listen to her with the feeling that I am listening to Plautus or Naevius: the actual sound of her voice is so unaffected and natural that she seems to produce no trace of display or affectation. Therefore, I infer that that was how her father and her ancestors used to speak - not harshly, like the person I mentioned, nor with a broad or countrified or jerky accent, but neatly and evenly and smoothly" (Equidem cum audio socrum meam Laeliam - facilius enim mulieres incorruptam antiquitatem conservant, quod multorum sermonis expertes ea tenent semper quae prima didicerunt - sed eam sic audio ut Plautum mihi aut Naevium videar audire: sono ipso vocis ita recto et simplici est ut nihil ostentationis aut imitationis afferre videatur; ex quo sic locutum esse eius patrem iudico, sic maiores, non aspere, ut ille quem dixi, non vaste, non rustice, non hiulce, sed presse et aequalibiter et leniter), see E.A. Hemelrijk, Matrona docta. Educated women in the Roman élite from Cornelia to Julia Domna (London and New York 1999), 77. 
typical for Graeco-Roman towns, such as civic munificence, priesthoods, and patronage, as well as to the public honour paid to female citizens.

Let us first return to the depiction of women in local dress on tombstones in the northern and north-western provinces: do these representations bear out the interpretation that these women wore native dress because they were hardly affected by Roman culture (or at least less so than men) and that this was due to their confinement to domestic life? This interpretation is hard to prove; moreover, there are other explanations that seem equally feasible. For instance, though acquainted with Roman costume, women may have used local dress in order to express their loyalty to their ethnic identity. The display of local costume, with its rich brooches, fibulae and torques, may have served to show their affluence (or that of their families) and their high status in the local hierarchy. Or indigenous dress may have expressed cherished notions of femininity, such as chastity or fertility. Thus, women's dress allows for several interpretations. Rather than women's supposed lack of acquaintance with Roman culture, a variety of reasons - including local prestige, ethnic identity, ideals of femininity, but perhaps also family pressure or a husband's wishes - may have been decisive for the choice of women's dress. ${ }^{5}$

As Ursula Rothe has recently noted, there are considerable regional differences in relation to dress and gender in funerary art within the northwestern provinces. Whereas in the middle Rhine and Ubian areas women often appear in local costume with their husbands in Roman dress, in the Treveran area it is the other way round: women sometimes appear in Roman clothes, while their husbands and sons wear a Gallic ensemble. Rothe also describes various compromises between Roman and native dress: some women are depicted in mixed ensembles or in a local garment

5 For various interpretations of women's dress in the Rhine-Moselle region, see Rothe 2009 , op. cit. (n. 2), 37-39, 44-47, 61-62, 65-6, 69-75: "the role of men in deciding female attire has often been overlooked" (p. 75, n. 811). She also discusses women as "guardians of ethnicity" (p. 66) and posits a gendered division of public and private (p. 71) as possible reasons for women's retention of native dress. Obviously, the local costume was better suited to the colder climate. According to Zanker 1992, op. cit. (n. 2), 346-347 women clung to their native tradition ("ein bewusstes Festhalten an den eigenen Traditionen im privaten Bereich"), whereas men, who identified with public life, adopted the image of the Roman citizen. Kremer 2004, op. cit. (n. 2), 152 assumes that there was a gradual change over time in favour of Roman dress for women in the provinces of Noricum and Pannonia; see also Rothe 2009, op. cit. (n. 2), 69: the majority of the stones from the Middle Rhine and Ubian areas showing women in native dress can be dated in the first and early second centuries. However, Galsterer 1992, op. cit. (n. 2), 381-382 and 388-389 notes a revival of (elements of) native dress (and names, deities and burial rites) in the second century. 
draped in a Roman manner. These different types of dress may be worn in the same period and sometimes even within the same family. ${ }^{6}$ Thus, the cultural meaning of dress is more complicated than it may appear at first sight. Apart from a gradual change over time in favour of Roman dress, especially in the cities, dress seems to be a matter of 'cultural choice', both for men and for women, and may have depended on the circumstances in which it was worn. A similar choice may have applied to names. In northern Africa, for instance, both Roman and indigenous names are found within the same family, and we find men using a Latin(ized) or an indigenous name on different (public or private) occasions. ${ }^{7}$ Thus, applying Andrew Wallace-Hadrill's notion of 'code-switching', we may perhaps suppose that some women stuck to local dress - or indigenous names - in private (which includes their portraits on tombs), but used Latin(ized) names and wore Roman dress when in public. ${ }^{8}$

In the provinces of the Mediterranean area - especially in northern Africa and southern and eastern Spain - women of the wealthy classes are represented in public wholly according to Roman fashion. Though most

6 For an example, see Rothe 2009, op. cit. (n. 2), 72 and 124 (T 26), see further 34-37, 42-43 and 69-77.

7 See Mattingly 2011, op. cit. (n. 1), 240, Galsterer 1992, op. cit. (n. 3), 378 and M. Carroll, Spirits of the Dead. Roman Funerary Commemoration in Western Europe (Oxford 2006), 258-259, on persons using a Roman or native name depending on the (public or private) occasion; see also J.N. Adams, Bilingualism and the Latin Language (Cambridge 2003), 213-229, on the use of Latin or Latinized names alongside Punic ones. For Roman and indigenous names alternating within the same family, see D. Cherry, 'Marriage and acculturation in Roman Algeria', Classical Philology 92.1 (1997), 71-83, Cherry 1998, op. cit. (n. 4), 86 and 101-140 and M. Corbier, 'Family and kinship in Roman Africa', in M. George (ed.), The Roman Family in the Empire: Rome, Italy and Beyond (Oxford 2005), 255-285; see also L.A. Curchin, 'Social relations in central Spain: patrons, freedmen and slaves in the life of a Roman provincial hinterland', Ancient Society 18 (1987), 87, on Roman and indigenous names in central Spain.

8 For the application of the linguistic notion of 'code-switching' to issues of Roman culture and identity, see A. Wallace-Hadrill, Rome's Cultural Revolution (Cambridge 2008). On 'code-switching' between Latin and vernacular languages, see Adams 2003, op. cit. (n. 7). For 'cultural choice', see R.R.R. Smith, 'Cultural choice and political identity in honorific portrait statues in the Greek East in the second century A.D.', Journal of Roman Studies 88 (1998), 56-93. Rothe 2009, op. cit. (n. 2), 69, also suggests that men and women wore different dress on different occasions. Tombs were the "most public of private monuments" (M. Koortbojian, 'In commemorationem mortuorum: text and image along the "street of tombs"', in J. Elsner (ed.) Art and Text in Roman Culture (Cambridge 1996), 225), and their portraits and inscriptions were intended mainly for the family and for fellow citizens. For an illuminating study of how tombs served family interests and indigenous agendas, see Mattingly 2011, op. cit. (n. 1), 246-268, on the monumental tombs at Ghirza in northern Africa. The stylized portrait busts depict (men and) women in local dress and jewellery (pp. 261-262). 
of these women were of local descent, their portrait statues and honorific inscriptions portray them as Roman by their full Roman dress and Latin or Latinized names. In the provinces of Spain, their dress often includes the stola, the symbol of the Roman (citizen) matrona, even in periods and statue types for which, in Italy, the stola is atypical. ${ }^{9}$ Though these women may have worn local dress or have spoken their native languages in private, their public statues and inscriptions present them as thoroughly assimilated to Roman culture. Unlike women of the northern and northwestern provinces, whom we mostly know from tombs, these honorific statues were set up in the public areas of the towns. Does this contrast between the northern and north-western regions and the Mediterranean area merely reflect a difference between public and private dress, or may we draw more far-reaching conclusions regarding the integration of women in these regions?

To answer this question, we should consider our second criterion: women's involvement in civic life, especially in those civic roles that were typical for Graeco-Roman towns and may be taken as a sign of their "Romanness". A quick glance at the chronological and geographical distribution of almost 1,200 inscriptions recording women's civic roles and public honour in the cities of Italy and the Latin West shows that they coincide with the pace of Romanization and urbanization in the western provinces (figs. 1 and 2). ${ }^{10}$ Italy provides the bulk of the evidence: forty-six percent of the inscriptions are from towns in Italy (with the almost total exception of Rome, where munificence and public honour came increasingly to be

9 C. Marcks, Formen statuarischer Repräsentation von Privatpersonen in Hispanien zur Zeit der Republik und in der Kaiserzeit (Cologne 2008), 19, 80, 115-118, 119-121, 129-130 and 167 , notes that, in the Spanish provinces, the stola is also found in statues of the early second century (when the stola was out of fashion in portrait statues from Italy) and in statues of the Eumachia-Fundilia type that, in Italy, do not show a stola. Moreover, in contrast to the north-western provinces, Noricum and Raetia, no (partly) indigenous dress is found in statues (whether male or female) in Roman Spain.

10 These figures are based on almost 1,200 inscriptions recording women's civic roles in Italy and the Latin West - as civic benefactresses, priestesses, and patronesses and "mothers" of cities and collegia - and their public honour by means of public portrait statues, honorific decrees, or public funerals granted them by the local council. About 250 additional inscriptions (almost all from Italy in the second and early third centuries) recording women's various other connections with collegia and their social 'networks' have not been taken into account here. All are discussed in E.A. Hemelrijk, Hidden Lives - Public Personae. Women and Civic Life in Italy and the Latin West during the Roman Principate (forthcoming). 
reserved for members of the imperial family). ${ }^{11}$ Yet, a considerable number, amounting to forty-four percent in total, are found in those provincial regions that were most highly Romanized and urbanized, namely Africa Proconsularis and Numidia (25\%), southern and eastern Spain (14\%) and, to a lesser extent, Gallia Narbonensis (5\%). The number of inscriptions increased steadily reaching its highest point in the period of the greatest prosperity, namely the second century and, for northern Africa, also the early third. By contrast, I have found virtually no evidence for women's civic roles in the more thinly urbanized provinces of the north-western part of the Empire, such as Britannia, Gallia Belgica, and Germania Inferior, and very little in neighbouring provinces such as Germania Superior, Gallia Aquitania, and Lugdunensis.

What conclusions may we draw from this distribution? First, how can we be sure that it is not merely the product of the spread of the "epigraphic habit"? Several differences between the distribution of my corpus of inscriptions and the spread of the "epigraphic habit" argue against this suggestion. The most striking are that there is virtually no epigraphic evidence for civic roles or public honour for women from the area with the highest "epigraphic density": the city of Rome, and from the militarized frontier zones. ${ }^{12}$ Furthermore, when compared to their male counterparts, women fulfilling civic roles - such as benefactresses, city patronesses, and (imperial) priestesses - are not only fewer, but also more narrowly limited to the most densely urbanized and Romanized Mediterranean regions. ${ }^{13}$ Of course, in respect of the scarcity of the evidence for women's civic roles

${ }^{11}$ W. Eck, 'Senatorial self-representation. Developments in the Augustan period', in F. Millar and E. Segal (eds), Caesar Augustus: Seven Aspects (Oxford 1984), 129-167; Id., 'Ehrungen für Personen hohen soziopolitischen Ranges im öffentlichen und privaten Bereich', in Schalles, von Hesberg and Zanker 1992, op. cit. (n. 2), 359-376, and G. Lahusen, Untersuchungen zur Ehrenstatue in Rom. Literarische und epigraphische Zeugnisse (Rome 1983), 97-107; see also E.A. Hemelrijk, 'Local empresses: priestesses of the imperial cult in the cities of the Latin West', Phoenix 61.3-4 (2007), 319-323.

12 On the much-debated issues of the "epigraphic habit" and "epigraphic density" (the number of surviving inscriptions per 1,00o square kilometres) see R. MacMullen, "The epigraphic habit in the Roman empire', American Journal of Philology 103 (1982), 233-46; E.A. Meyer, 'Explaining the epigraphic habit in the Roman empire: the evidence of epitaphs', Journal of Roman Studies 80 (1990), 74-96; G. Woolf, 'Monumental writing and the expansion of Roman society in the early Empire', Journal of Roman Studies 86 (1996), 22-39 and Id., Becoming Roman: The Origins of Provincial Civilization in Gaul (Cambridge 1998), 82-105. For the exceptional position of the city of Rome, see the preceding note.

13 E.A. Hemelrijk, 'City patronesses in the Roman Empire', Historia 53.2 (2004), 209-245; Ead., 'Priestesses of the imperial cult in the Latin West: titles and function', Antiquité Classique 74 (2005), 137-170 and Ead. forthcoming, op. cit. (n. 10). 


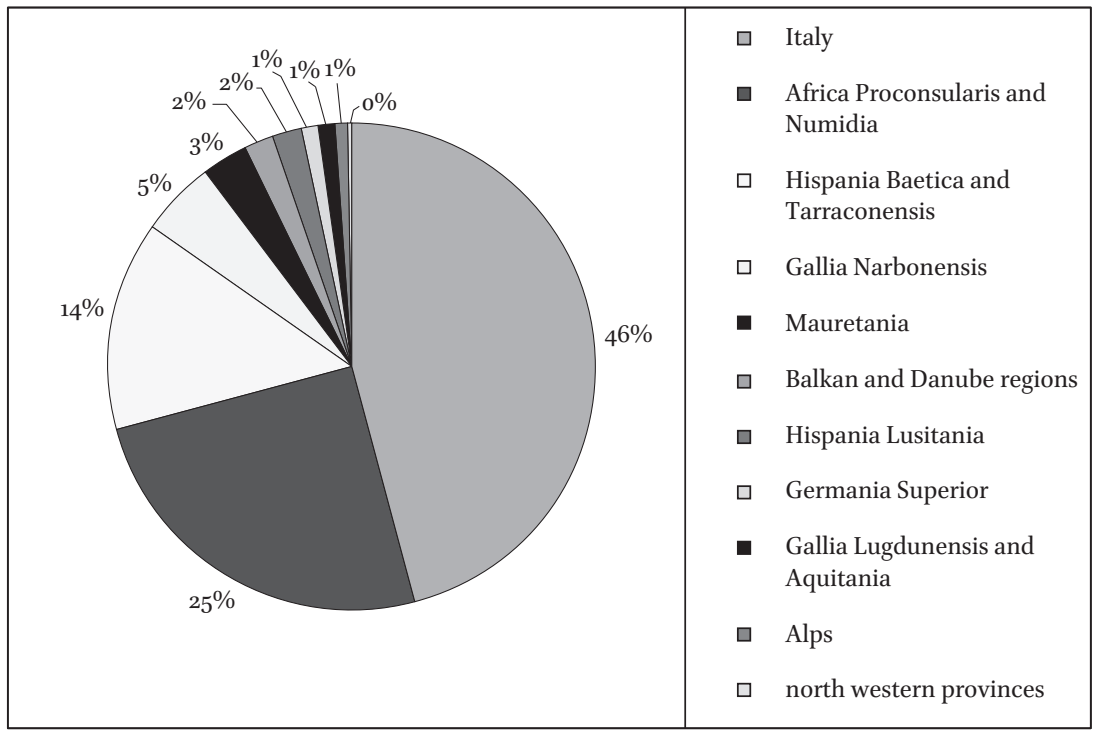

Figure 1: Geographical distribution

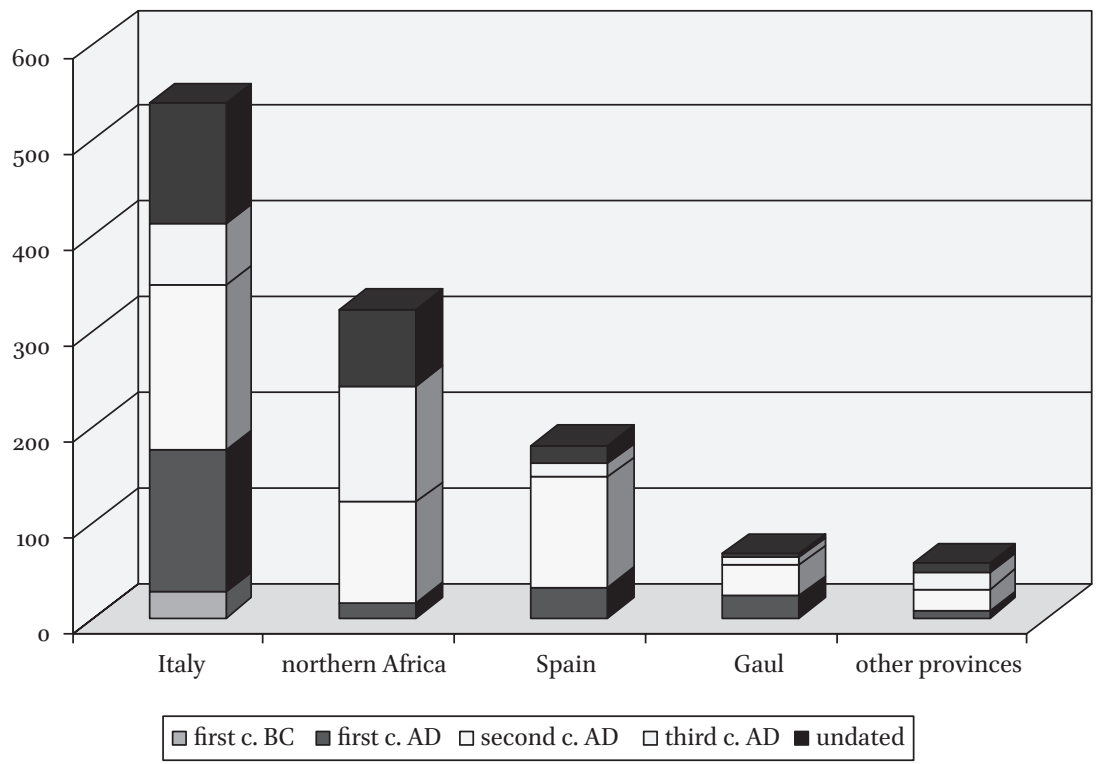

Figure 2: Geographical and chronological distribution 
in the north-western provinces, we must take into account the lower "epigraphic density" of these regions. However, even when offset against the epigraphic totals for each province, the distribution of my corpus shows a particularly low percentage for the north-western provinces. ${ }^{14}$ Taken together, these differences strongly suggest that there must be other reasons for the distribution.

Let us therefore turn to the interrelated processes of Romanization, urbanization, and economic prosperity in the Mediterranean regions between the late first and the early third centuries. To what extent did they encourage the participation of women? Apart from providing the material and mental preconditions for munificence and civic priesthoods, the increase in the number and prosperity of Roman cities and the spread of Roman citizenship and Roman civil law had great consequences for women of the wealthier classes. ${ }^{15}$ This holds especially for the laws of inheritance, which allowed for equal portions for sons and daughters in case of intestacy, and for the separation of property between husband and wife in Roman marriage without manus. Moreover, the Augustan ius liberorum gave female Roman citizens who were sui iuris and had three or more children full legal capacity as property owners. Even when still

14 The numbers of inscriptions in my corpus have been compared to the CIL totals for the same provinces in the Frankfurt database, which also covers recent $C I L$ supplements. They vary between $2.42 \%$ for Baetica and $0.05 \%$ for the north-western provinces (Britannia, Gallia Belgica, and Germania Inferior). If compared to all inscriptions per province in the Frankfurt database (which includes the $A E$ and other epigraphic corpora) the percentages vary between $1.56 \%$ for Baetica and $0.02 \%$ for the north-western provinces. I thank Anna Sparreboom for the calculations.

15 For the spread of Roman citizenship and Roman law - even among civitates that were not compelled to use Roman law - see, among others, A. Lintott, Imperium Romanum. Politics and Administration (London and New York 1993), 129-145 and 154-16o (on Roman and indigenous law), and A.T. Fear, Rome and Baetica. Urbanization in southern Spain c. 50 BC-AD 150 (Oxford 1996), 152-156 and 162-169 (on interpretatio peregrina and various degrees of adoption of Roman law in peregrine communities). On legal pluralism and choice of law in dealings between Roman citizens and foreigners before Caracalla, see the articles of Clifford Ando and Hannah Cotton in the present volume. Whereas these articles are mainly concerned with the use of local law, I am especially interested in the application of Roman law. That Roman family law was actually applied in local cities is apparent, for example, from the Flavian municipal charter of Irni in Spain, ch. 21, $22,29, \mathrm{~B}$ and 56 on potestas, manus, tutela and the ius liberorum, and ch. 86 on the use of patria potestas in non-Roman families; see J. González, "The Lex Irnitana: a new copy of the Flavian municipal law', JRS 76 (1986), 147-243 and J.F. Gardner, 'Making citizens: the operation of the Lex Irnitana', in L. de Blois (ed.), Administration, Prosopography and Appointment Policies in the Roman Empire (Amsterdam 2001), 215-229. Municipal charters, like that of Irni, stimulated non-Roman citizens, too, to live according to Roman law, by dealing with them as if they were Roman citizens, see J.F. Gardner, Being a Roman citizen (London 1993), 188-190 and Ead., 'Making citizens'. 
in tutela, women in the imperial period were not much hampered; or, in the words of Jane Gardner: "where property is concerned, the legal capacity of Roman men and Roman women is virtually the same". ${ }^{16}$ Thus, the spread of Roman citizenship and Roman law gave female Roman citizens of wealthy families unprecedented legal and financial capacities.

The financial independence of married women sui iuris, which is attested in Italy from the late first century вс onwards, gave rise, in the second and early third centuries, to a class of wealthy female landowners and businesswomen in the most densely urbanized and Romanized Mediterranean provinces. ${ }^{17}$ According to a recent estimate, the spread of Roman citizenship and Roman civil law in these regions brought thirty to forty-five percent of private property into the hands of women, mainly through inheritance. ${ }^{18}$ Even if this estimate is too high, the accumulation of wealth in the hands of certain women, and their legal capacity to use it, made them a force to be reckoned with. In comparison to their male peers, women may even have had greater riches, since they did not need money for a political career. This is in agreement with my corpus of inscriptions, where we find women not only among the donors of smaller gifts but, contrary to what is usually believed, especially among the most gener-

16 J.F. Gardner, 'Gender-role assumptions in Roman law', Échos du Monde Classique / Classical Views 39, n.s. 14 (1995), 393; see also R.P. Saller, 'Pater familias, mater familias, and the gendered semantics of the Roman household', Classical Philology 94 (1999), 182-197. For a clear survey of the effects of Roman civil law on women, see J.F. Gardner, Women in Roman Law and Society (London 1990, 3rd edition); Ead. 1993, op. cit. (n. 15), 85-109 and Ead., 'Gender-role'; see also S. Treggiari, Roman Marriage. Iusti Coniuges from the Time of Cicero to the Time of Ulpian (Oxford 1991), on Roman marriage and the ius liberorum.

17 E.W. Haley, Baetica Felix. People and Prosperity in southern Spain from Caesar to Septimius Severus (Austin 2003), 135-170, on wealthy male and female oil merchants, landowners, pottery producers and owners of figlinae (clay-beds) in imperial Baetica; see also Mattingly 2011, op. cit. (n. 1), 146-166 and R.P. Duncan-Jones, 'Economic Change and the Transition to Late Antiquity' in S. Swain and M. Edwards (eds), Approaching Late Antiquity. The Transformation from Early to Late Empire, (Oxford 2004), 20-52, on the economic growth of Africa Proconsularis and Numidia in the 2nd and 3 rd centuries AD. See also the article by Anthony Álvarez Melero in this volume on the wealth of women of equestrian rank and the sources of that wealth.

18 A. Arjava, Women and the Law in Late Antiquity (Oxford 1996), 70-71. The much lower percentage (roughly twenty percent) implied by Champlin's discussion of female testators - E. Champlin, Final Judgments. Duty and Emotion in Roman Wills, 200 B.C.-A.D. 250 (Berkeley, Los Angeles and Oxford 1991), 103-130 - is disproved by J. Pölönen, 'The division of wealth between men and women in Roman succession (c.a. $5^{\circ}$ BC - AD 250)', in P. Setälä et al. (eds), Women, wealth and power in the Roman Empire (Rome 2002), 147-179, who argues for a more equal division of inherited wealth between men and women, in which women received "at least forty to fifty percent of all private property in inheritance practice in ancient Rome" (p. 179). 
ous benefactors financing public buildings such as temples, bathhouses, amphitheatres and aqueducts. ${ }^{19}$ As a reward, many of them were honoured with one or more public statues, which sometimes included their families. Annia Aelia Restituta, for example, received five public statues because of her promise to build a theatre in her hometown of Calama in Numidia. ${ }^{20}$ And Iunia Rustica, perpetual priestess in Cartima in southern Spain, was granted public statues of herself and her son because of her lavish benefactions. Pleased with the honour, she bore the costs herself and added a statue of her husband, thus forming a family group. ${ }^{21}$

Obviously, my corpus of inscriptions is no random sample. Forty percent of the provincial women mentioned in them belonged to the elite, and all must have been among the most wealthy, and probably most ambitious, women in their towns (fig. 3). This also holds for the small percentage of women of freed families (4\%), many of whom were related to Augustales; their munificence and priestly functions on behalf of their cities furthered the careers and upward mobility of their sons and descendants. ${ }^{22}$ That the social status of a large number of women $(56 \%)$ is unknown to us is partly due to the absence of status indicators for women in epigraphic texts. Apart from the title clarissima femina, which came into fashion for women of senatorial rank in the middle of the second century, there is no clear terminology for female rank. The term stolata femina is rare in inscriptions in the Latin West, and its designation of equestrian rank not

19 Hemelrijk forthcoming, op. cit. (n. 10) contra J.R. Patterson, Landscapes and Cities. Rural Settlement and Civic Transformation in Early Imperial Italy (Oxford 2006), 173.

20 Annia Aelia Restituta (Calama, Num; 161-169): ILAlg. I, $287=$ CIL VIII, 5366: ordo univer/sus statua[s] n(umero) quinq(ue) de pu[bl(ico)] faciend[as] / decreuit; ILAlg I, 286 = CIL VIII, 5365 = 17495: or/do ob eam causam sta/tuas quinque de pu/blico pon [i] censuis/set.

21 CIL II, 1956 = ILS 5512 = ILMMalaga 6 (Cartima, Hisp.Baet. late 1st c.): Iunia D(ecimi) f(ilia) Rustica sacerdos / perpetua et prima in municipio Cartimitan[o] / porticus public(as) uetustate corruptas refecit solum / balinei dedit vectigalia publica vindicavit signum / aereum Martis in foro posuit porticus ad balineum / solo suo cum piscina et signo Cupidinis epulo dato / et spectaculis editis d(e) p(ecunia) s(ua)d(edit) d(edicauit) statuas sibi et $C$ (aio) Fabio / Iuniano f(ilio) suo ab ordine Cartimitanorum decretas / remissa impensa item statuam C(aio) Fabio Fabiano uiro suo / d(e) p(ecunia) s(ua) f(actas) d(edit). "Iunia Rustica, daughter of Decimus, first and perpetual priestess in the municipium of Cartima, restored the public porticos that were ruined by old age, gave land for a bathhouse, reimbursed the public taxes, set up a bronze statue of Mars in the forum, gave at her own cost porticos next to the bathhouse on her own land, with a pool and a statue of Cupid, and dedicated them after giving a feast and public shows. Having remitted the expense, she made and dedicated the statues that were decreed by the council of Cartima for herself and her son, Gaius Fabius Iunianus, and she likewise made and dedicated at her own cost the statue for Gaius Fabius Fabianus, her husband".

22 See, among others, S.E. Ostrow, 'The Augustales in the Augustan Scheme', in K.A. Raaflaub and M. Toher (eds), Between Republic and Empire. Interpretations of Augustus and his Principate (Berkeley, Los Angeles and Oxford 1990), 370. 


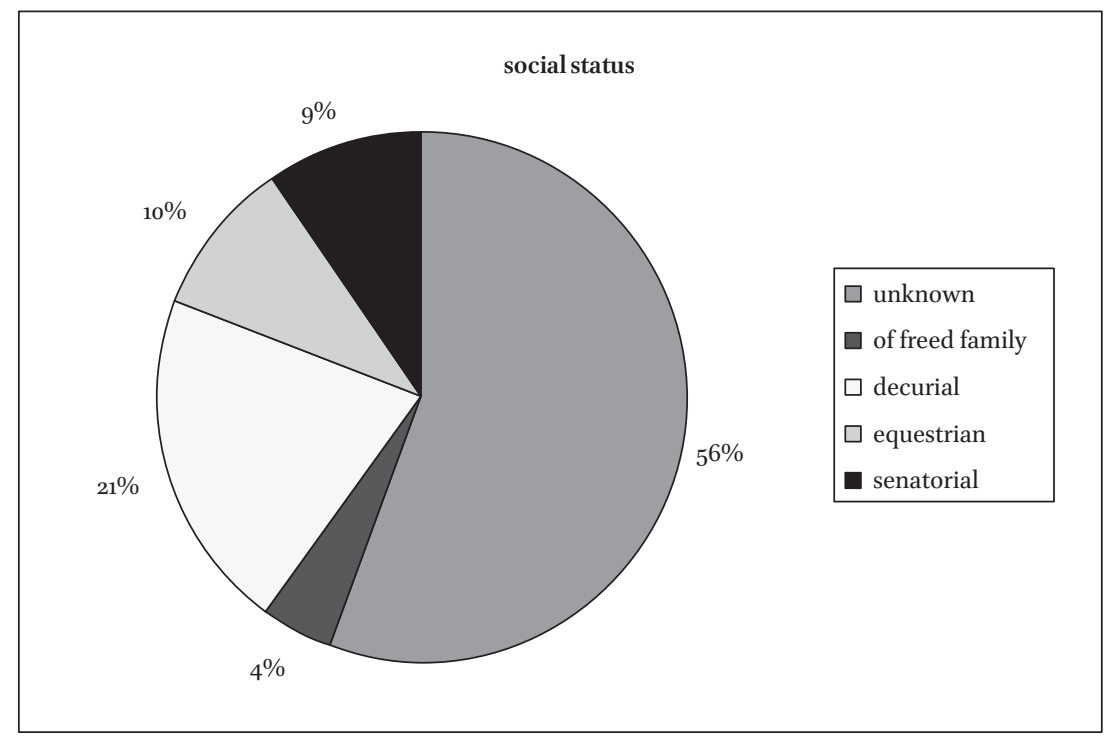

Figure 3: Social status of women in civic roles in the Western Provinces $(n=628)$

always beyond doubt. In the absence of a clear terminology, it is hard to make out whether a woman was of equestrian or decurial family; the surest indication is the career of her husband or father, but this is often unknown. ${ }^{23}$ Thus, more women may have belonged to families of the decurial or equestrian orders than is here recorded. Nevertheless, the majority of the women whose social status is unclear probably did not belong to families of the political elite but to wealthy rising families of what we may somewhat anachronistically call the "upper-middle class". By their benefactions, priesthoods and public statues, these women won public recognition for themselves and furthered the social status of their families.

23 On the title clarissima femina for women of senatorial rank, see M-Th. RaepsaetCharlier, 'Clarissima femina', Revue Internationale des Droits de l'Antiquité 28 (1981), 189212. As an indicator of equestrian rank, the title stolata femina seems restricted to the late second and third centuries, see B. Holtheide, 'Matrona stolata - Femina stolata', Zeitschrift für Papyrologie und Epigraphik 38 (1980), 127-31. J. Edmondson, 'Public dress and social control in late republican and early imperial Rome', in J. Edmondson and A. Keith (eds), Roman dress and the fabrics of Roman culture (Toronto 2008), 24 regards it as the equivalent of the more frequent honesta femina, but honesta does not always indicate equestrian rank; in some cases, it seems a moral qualification rather than an indication of rank. For women's indirect relation to the elite orders, see Hemelrijk 1999, op. cit. (n. 4), 11-12 with further references. 
Virtually all women in my corpus were Roman citizens, but sometimes their local birth shines through in their names and in those of their relatives. The combination of indigenous or Latinized elements in names such as Caecilia Zaba, Fabia Bira, Nahania Victoria, Cornelia Sillibor, and Moccia Silvina reflects their complicated social identity, which was both indigenous and Roman. ${ }^{24}$ This did not prevent them from presenting themselves in public as typically 'Roman' women, conforming in dress and behaviour to Roman custom. They held priesthoods in the cults of 'Roman' deities (including the imperial cult) and embellished their cities according to the Graeco-Roman tradition of euergetism. Especially in the early Empire, when Roman citizens were comparatively rare outside Italy, the display of Roman citizenship and familiarity with Roman culture must have brought great prestige. Its privileges and prizes were desired, and advertised, not only by men but - as is apparent from my corpus also by women. Their honorific statues portray them according to Roman fashion, and (more often than in Italy) these statues were set up in the most prestigious location, the forum. ${ }^{25}$ By contrast, in the northern and north-western provinces, the slower spread of Romanization and Roman citizenship, and the lower level of urban density and prosperity, seem to have had a negative influence, especially on women, who are virtually absent from the public domain. Some scholars believe that their position deteriorated under Roman rule as compared to the pre-Roman period, but the evidence for women in these regions before the Roman conquest is too limited, and regionally too disparate, to allow comparison. ${ }^{26}$

So, what may we conclude as to the integration of women into Roman society and the factors that stimulated, or hampered, their integration? First, that "women" as a category is too broad and undifferentiated to

24 Caecilia Zaba, great-priestess of Ceres(?): CIL VIII, 10575 (Saltus Burunitanus, Afr. Proc. 2nd c.); for Fabia Bira, daughter of Izelta and wife of M. Valerius Severus, son of Bostar, flaminica prima of Volubilis (Maur. Ting.) in the mid first century and Nahania Victoria, flaminica perpetua of Thugga (Afr. Proc. 184-192), see Hemelrijk 2005, op. cit. (n. 13) and Ead., 'Priestesses of the imperial cult in the Latin West: benefactions and public honour', Antiquité Classique 75 (2006), 85-117. Cornelia Sillibor (or daughter of Sillibor): CIL $\mathrm{II}^{2} / 7,5=$ = CIL II, $335^{1}=$ CILA 3.1, 339 (Ossigi Latonium, Hisp. Baet., early first c.). Moccia Silvina, benefactress of the local collegium centonariorum: CIL XII, 2824 (Ugernum, Gall. Narb.).

25 Hemelrijk forthcoming, op. cit. (n. 10).

26 See L. Allason-Jones, Women in Roman Britain (London 1989), 190, and R. Hingley, 'Domestic organisation and gender relations in Iron Age and Romano-British households', in R. Samson (ed.), The social archaeology of houses (Edinburgh 1990), 141, on women in Iron Age Britain. 
draw valid conclusions: not only are there considerable regional differences, but there were also other distinctions, such as social status, wealth, age, and residence, that influenced the degree of their integration. Women of wealthy families in the Mediterranean regions seem to have benefited most from the spread of Roman citizenship and law, and from the growing urban prosperity. Though excluded from politics and outnumbered by male benefactors and imperial priests, their wealth, and their legal capacity to use it, gave these women a public face. By spending their money for the embellishment of their cities, and by holding expensive priesthoods, they gained prestige for themselves and for their families. Like their male counterparts, though less frequently, they were granted honorific statues and public funerals, and some were officially co-opted as a patroness or a 'mother' of a city or collegium. ${ }^{27}$ Thus, these wealthy women in Roman cities of the Mediterranean regions may truly be regarded as fully integrated into Roman society. Of course, this does not preclude the possibility that they retained local traditions and used their native languages in private. ${ }^{28}$

By contrast, women of the poorer classes, and women living in rural areas in the north-western regions, may indeed have lagged behind. Before the general grant of Roman citizenship in 212, few of them seem to have been Roman citizens and, being poor, most were unable to benefit from the advantages of Roman marital law. Possibly, as has been suggested by some, Roman rule may even have worked against their integration, since it favoured the men of their class, who entered into direct contact with Romans and Roman habits as craftsmen, traders, or soldiers. ${ }^{29}$ Roman culture and rulings, such as the marriage ban for Roman soldiers before

27 E.A. Hemelrijk, 'Patronesses and "mothers" of Roman collegia', Classical Antiquity 27.1 (2008), 115-162; Ead. 2004, op. cit. (n. 13) and Ead., 'Public Roles for Women in the Cities of the Latin West', in S.L. James and S. Dillon (eds), A Companion to Women in the Ancient World (London 2012), 478-490.

28 See, for instance, Mattingly 2011, op. cit. (n. 1), 239-240, and Adams 2003, op. cit (n. 7), 213-235, on the continued use of Punic, also among members of the local elites.

29 Cf. Cherry 1998, op. cit. (n. 4), 157 on women in northern Africa: "I suspect that the Roman occupation of north Africa may in fact have served to undermine the position of women in indigenous society, because men are likely to have received a much greater share of the favours that the Roman state routinely dispensed to those provincials who collaborated in military and civilian government". See also n. 26 above. Cherry seems to include women of the elite, which - as I hope to have shown - is not justified. The notions "discrepant experience" and "discrepant identities", coined by Mattingly 2011, op. cit. (n. 1), 203-245, seem useful here to understand the different experiences of Roman rule among women of different regions, domicile (urban or rural), wealth, and social standing. 
the reign of Septimius Severus, ${ }^{30}$ may have undermined the position of indigenous women of these classes, who in a changing world may have lost whatever status they had previously enjoyed, without receiving a new one in return. Though this is speculative, it may explain the disparity in our evidence. Whereas women of wealthy urban families in the Mediterranean regions profited from the spread of Roman citizenship and Roman law, women of the poorer, rural classes and regions seem to have been only marginally, or perhaps at first even negatively, affected by Roman influence. Thus, Roman rule may have had opposite effects on different groups of women, depending on differences in wealth, social status, and residence. Though Roman rule did affect all women, it did not have the same effect on all. The resulting diversity in attitudes - ranging from pride in Roman citizenship to loyal adherence to indigenous traditions, or to code-switching between the two depending on circumstances - seems to be reflected in the differences in dress and names on honorific statues and tombstones in the western provinces of the Roman Empire.

30 See S.E. Phang, The Marriage of Roman Soldiers (13 B.C.-A.D. 235). Law and Family in the Imperial Army (Leiden, Boston, Cologne 2001) on the marriage of Roman soldiers and the financial disadvantages of a soldier's family; cf. also B. Campbell, 'The marriage of soldiers under the Empire', Journal of Roman Studies 68 (1978), 153-166, on the problems suffered by soldiers, their 'wives' and their children because of the ban. 